\title{
SERVICE QUALITY PERFORMANCE MEASUREMENT PROVIDED BY A VEGAN SAVOURY SNACKS COMPANY: APPLICATION OF THE SERVQUAL TOOL ON ORDERS THROUGH A FOOD DELIVERY APP
}

\author{
MENSURAÇÃO DO DESEMPENHO DA QUALIDADE DOS SERVIÇOS \\ PRESTADOS EM UMA EMPRESA DE SALGADOS VEGANOS: \\ APLICAÇÃO DA FERRAMENTA SERVQUAL EM PEDIDOS VIA \\ APLICATIVO DE DELIVERY
}

\section{MEDÍCION DEL DESEMPEÑO DE LA CALIDAD DE LOS SERVICIOS PRESTADOS EN UNA EMPRESA DE BOCADITOS SALADOS VEGANOS: APLICACIÓN DE LA HERRAMIENTA SERVQUAL EN PEDIDOS VÍA APLICACIÓN DE DELIVERY}

\author{
Rafael de Almeida Martarello ${ }^{1}$ \\ Mariana Roman Oliveira ${ }^{2}$ \\ Article received in April 2021 \\ Article accepted in September 2021
}

\begin{abstract}
Distant relationships with the client have gained predominance and become necessary during the period of social distancing. Faced with this new scenario, it has become essential to measure the quality of services provided in relation to consumer expectations and requirements. The aim of this study is to assess the quality of services of a vegan company which provides fried and baked savories through a delivery app. To collect data on the quality of service provided by the micro business, interviews and direct observation were used as well as the completion of the SERVQUAL questionnaire by the consumers. Analysis of this data showed a positive result in the large majority of the evaluated aspects and client expectations of this kind of service were identified. Most criteria were positively influenced by the delivery app. We can therefore conclude that the service offered contributes in a positive way to the client's perception of quality of service. It should also be mentioned that most of the criteria are influenced by the delivery app, thus highlighting it as a relevant tool for organizational dynamics.
\end{abstract}

Key words: Shared Economy. SERVQUAL. Veganism. Delivery.

\section{RESUMO}

As ações de relacionamento à distância com o cliente têm ganhado preponderância e se tornaram necessárias durante o período de distanciamento social. Frente a este cenário, manifesta-se a necessidade da mensuração do desempenho da qualidade dos serviços prestados em relação às

\footnotetext{
${ }^{1}$ Doutorando pela Unicamp. E-mail: martarellorafael@gmail.com.

${ }^{2}$ Graduanda pela Universidade Virtual do Estado de São Paulo. E-mail: mari_roman32@ yahoo.com.br.
}

Refas - ISSN 2359-182X v.8, n.1 
expectativas e necessidades dos consumidores. O objetivo deste estudo é avaliar a qualidade de serviços de uma empresa vegana do ramo de salgados fritos e assados realizados com o uso de um aplicativo de delivery. Para isto, são utilizados como procedimentos técnicos para coletar informações sobre a microempresa a entrevista e observação direta e para captar os dados sobre qualidade no serviço, a aplicação do questionário do modelo SERVQUAL com consumidores. Empreendida a análise SERVQUAL, foi encontrado resultado positivo em ampla maioria dos aspectos avaliados, além da identificação das expectativas dos clientes acerca deste tipo de serviço. A maioria dos critérios sofreu a influência positiva do aplicativo de delivery. Desta maneira, podemos concluir que o serviço ofertado contribui positivamente para a percepção por parte do consumidor da qualidade do serviço. Resta ainda mencionar que maioria dos critérios passa pela influência do aplicativo de delivery, evidenciando este como uma relevante ferramenta para a dinâmica organizacional.

Palavras-chave: Economia Compartilhada. SERVQUAL. Veganismo. Delivery.

\section{RESUMEN}

Las relaciones a distancia con los clientes han ganado preponderancia y se hacen necesarias durante el período de distanciamiento social. Ante este nuevo escenario, se manifiesta la necesidad de medir la calidad de los servicios prestados en relación con las expectativas y necesidades de los consumidores. El objetivo de este estudio es evaluar la calidad de los servicios de una empresa vegana que ofrece bocadillos fritos y horneados mediante una aplicación de delivery de comida. Como procedimientos técnicos para recolectar información sobre la microempresa utilizase entrevistas y observación directa, así como el cuestionario SERVQUAL por parte de los consumidores para capturar los datos sobre la calidad en el servicio. El análisis encontró un resultado positivo en la gran mayoría de los aspectos evaluados, además se identificaron las expectativas de los clientes de este tipo de servicio. La aplicación de delivery de comida influyó positivamente en la mayoría de los criterios. Así, podemos concluir que el servicio ofrecido contribuye positivamente a la percepción del consumidor sobre la calidad del servicio. Resta mencionar que la mayoría de los criterios están influenciados por la aplicación de entrega, destacándola como una herramienta relevante para la dinámica organizacional.

Palabras clave: Economía Compartida; SERVQUAL; Veganismo; Delivery.

\section{INTRODUCTION}

Currently, the literature attributes to the service economy the responsibility for absorbing a large number of jobs, not only for the high contingent of labor resulting from the deindustrialization process of the 1980s, but also for the opening of new economic enterprises and attractiveness. Responsible for 3/4 of the value added in a product (QUINN; GAGNON, 1986; GRÖNROOS, 1995), including in Brazil, the service sector has had a predominant share of the country's GDP for over seven decades and currently accounts for $75.8 \%$ of the Brazilian GDP (NETO, 2019).

The service sector is more resilient to recession cycles. This is due to the tendency of consumers to suspend the purchase of products instead of sacrificing the services used. Another relevant point is the cyclical and continuous pattern of service demand, which certain products do not have. Another point generally raised is that organizations in services currently have been under a lot of pressure from external markets. Although this statement is correct, it is necessary to mention that many services are in a more comfortable position, since in order to have competition, the person or organization providing services needs to be physically in contact with consumers in a given territory. 
When consulting the household consumption structure, the average household expenditure on food is $17.5 \%$ in relation to total consumption expenditure. Within this expense, spending on food away from home in urban areas was $33.9 \%$, a number that has been growing in the 2002-2018 historical series (INSTITUTO BRASILEIRO DE GEOGRAFIA E STATÍSTICA, 2019).

Regarding the consumption of fried and baked snacks, in 2009, 53.2\% were consumed away from home (INSTITUTO BRASILEIRO DE GEOGRAFIA E STATÍSTICA, 2011), with an average per capita food consumption of 10.1 grams per day. A situation that in 2018 increased to $40.1 \%$ of consumption of these items outside the home and 8.7 grams per day was consumed by families (INSTITUTO BRASILEIRO DE GEOGRAFIA E STATÍSTICA, 2020).

The consumption of food produced outside the home is already something Brazilian's daily life and no longer reserved for special occasions or events. This change is due to factors such as convenience, increased quality of life and diversity of options. However, with the public health measures resulting from the COVID-19 pandemic, the bars and restaurants sector was severely impacted by layoffs, lack of payment, reduced sales, closing of units, shortage of supplies (ASSOCIAÇÃO NACIONAL DE RESTAURANTES; GALUNION, 2020; CARVALHO; LAMEIRAS; MORAES, 2020).

In this moment of social distance, most economic enterprises in the food service sector are working only with delivery (ASSOCIAÇÃO NACIONAL DE RESTAURANTES and GALUNION, 2020). Currently, the forms used by this sector have been: Delivery through platforms and applications (72\%); Sales by WhatsApp (62\%); Delivery by own brand application (44\%); Sales via social media (42\%); Digital menus by QRCode (38\%); Online consumer payments (34\%); Sales by website / e-commerce (21\%); Online bookings (16\%); and Self-service Totem (14\%) (ASSOCIAÇÃO NACIONAL DE RESTAURANTES; GALUNION, 2020).

With this, the actions of long-distance relationship with the customer have gained preponderance, either with the introduction of new means, or by the continuity of the means already used. This makes it possible to maintain and in some cases expand economic activities. Added to this, one of the main challenges for survival and business recovery is the incorporation of management and sales tools digitally.

Unsurprisingly, small businesses do not have the habit, resources and intellectual tools to measure the quality of the services provided, in addition, in situations of crisis, they choose to reduce costs that reflect on the quality of the service provided. Given this new normality, which shows the need for hygiene and safety protocols and gives rise to a new consumption behavior, this study aimed to answer the following question: what is the quality offered by the company VegXYZ to its delivery customers? For this, the objective of this study is to evaluate the quality of services of the company VegXYZ performed through orders via a delivery application. For this, the SERVQUAL questionnaire was applied in a vegan microenterprise in the fried and baked snacks sector. 


\section{THEORETICAL BACKGROUND}

The theoretical framework starts with the vegan consumer.

\subsection{Vegan consumer}

The study of consumer behavior provides a personalized view of the needs, attitudes, decision factors, purchasing power, strategies and means of consumption of each segment. This is obtained through the inquiry of what is purchased, by whom it is purchased, what are the purchase motivations and the characteristics and experiences of the purchase process, and what is the frequency of purchase and consumption (SCHIFFMAN AND KANUK, 2000; CERETTA AND FROEMMING, 2011).

Veganism is a praxis that opposes animal exploitation in a broad sense and defends the emancipation of animals in society. Supporters of this social positioning, in addition to maintaining a political position on the abolition of the exploitation of all animals, do not carry out any type of consumption, work or entertainment based on animal exploitation (BAPTISTELLA; ABONIZIO, 2017).

The number of vegan people is still an imprecise figure, in general, surveys unite this audience as vegetarian and/or vegan. Studies show the figure of $4 \%$ of the Brazilian population, although this number varies according to the size of the city and region (IBOPE, 2012, RIBEIRO, 2019; BARROS, 2019).

Consumers considered vegan are growing, as is the potential of this market (RÉVILLION et al., 2020). In the same direction, the number of companies, brands, specialized products, as well as vegan versions of traditional products are growing (RIBEIRO, 2019). These commercial ventures, in general, face a great operational challenge: to maintain a supply chain that meets the demand and follow the same principles and practices.

From a psychographic cut, it is verified in this market niche that the profile of the vegan consumer is based on a deeply conscious and critical consumption ethics, in addition to the consumption serving as an identity construction of this group.

Vegan consumers' consumption decisions are focused on avoiding animal products. In practical terms, vegans do not practice a diet composed of items of animal origin, such as meat, milk and dairy products, egg and honey, nor do they use clothing from animals such as leather, wool, silk, among others. In addition, vegans avoid the consumption of products that are tested on animals or that contain ingredients of animal origin in their composition, such as cosmetics and medicines (RIBEIRO, 2019). These consumers also do not support attractions that present animal exploitation and are against the trade in animals (FREIRIA et al., 2017). Finally, there is concern about environmental impacts and the nutritional well-being generated.

\subsection{Logistics and the SERVQUAL scale}

In the popular imagination, the logistics sector is responsible for activities of physical distribution of products and stock management, however the activities assigned and under the co-responsibility of this sector are much more numerous. The mission of logistics can be understood as "the placement of the right product, in the right quantity, in the right place, on time, with the right quality, with the right documentation, at the right cost, producing at the 
lowest cost, in the best way, displacing more quickly, adding value to the product" (ROSA, 2014, p.17).

On the other hand, companies in the service sector also organize their logistical activities, but in a different way due to the particularities of the services. To be constituted as a service activity, there must be the following characteristics: business practice beyond the physical limits of the business establishment; creation of social relationships, understood as the contact between provider and client, regarded as the Moment of Truth; intangible aggregate as a result of the process (KOTLER and ARMSTRONG, 2015); enable the satisfaction of needs that are not only physical but also subjective; perpetual variability of execution (ANTUNES, 2011); to be able or not to be accompanied by a good; be produced and consumed simultaneously and, for the latter, have an unlikely level of stock (QUINN and GAGNON, 1986). These mentioned characteristics make measuring the quality of services more complex than in physical products (GRÖNROOS, 1995; ANTUNES, 2011).

Currently, in the competitive dynamics, companies are driven to provide increasing levels of quality that not only meet customer needs, but also offer greater satisfaction than competing companies. In this way, we will seek to satisfy consumers' needs in terms of speed, quality, reliability, availability, absence of defects and cost, while at the same time obtaining profitability through a specific aggregate of services and efforts.

This adequate level of services that makes it possible to fulfill the logistical mission and meet the customer's needs is called customer service level. And, through it, the organization must "exceed the expectations of consumers in relation to the value and quality they perceive" (TOMOYOSE, 2014, p.26).

In this context, the organization decides on aspects such as: conduct in case of errors and unforeseen events; selection of the way the service is made available; deadline administration; support and after-sales services; auxiliary stock level; order processing policies; and tracking information flow to the customer. These aspects have a direct relationship with the result in the number of sales, market share dominance, profitability, supplier loyalty and customer loyalty.

In particular, order processing interferes with the time taken to complete the order cycle. Order preparation, transmission, receipt and fulfillment, shipping, and reporting activities represent a considerable portion of the total order cycle time. On the other hand, with the advancement of information and communication technologies, this stage has benefited from cost reduction, greater agility, automation, security, reliability, greater interconnection of information and greater convenience for the chain.

These organizational activities must be measured and controlled so that there is a parameter for their respective management. It is also necessary to identify the vital satisfaction factors of the respective business customer. To be guided by this idea is to put the consumer at the center of the business by seeking, at the very least, to reach their expectations. In the field of logistics, there are several performance indices, one of the best known and service-oriented ways of measuring performance is the SERVQUAL Scale (Service Quality Gap Analysis).

This established model is based on an approach that uses objective measures to relate perceived quality and users' expectations to measure service quality performance. In this way, the superiority in the quality of services would be given if the expectations and needs of users are exceeded (PARASURAMAN; ZEITHAML; BERRY, 1988). Mathematically, this equation would be given by subtracting the perceptions the user had from given quality factors by the expectation he had. 
In this model, the quality of service is linked to five dimensions. The first call for Tangible, which deals in general with the physical structure of the establishment, from auxiliary accessories, equipment to the appearance of employees. The second is Confidence, which is the performance to fulfill the offer. The third is called Responsiveness and refers to goodwill and immediate service. The fourth deals with the guarantee transmitted to the user by knowledge and courtesy and is known as Security. Finally, the last dimension is Empathy, which is demonstrated by individualized care and customer care (PARASURAMAN; ZEITHAML; BERRY, 1988).

By using SERVQUAL analysis, it is possible to discover the level of quality that the company is offering, as well as the level of quality that the customer wants and perceives. In addition, through the gaps offered by the tool's analysis, it is possible to find discrepancies that can outline quality problems, the so-called five Gaps/Failures.

According to Parasuraman, Zeithaml and Berry (1985), GAP 1 is the result of a discrepancy between the customer's expectation and the manager's perception. GAP 2 appears from the manager's perception of consumer expectations and service quality specifications. In turn, GAP 3 is seen as a divergence between service quality specifications and the service actually delivered. GAP 4 is related to the divergence between the service delivered and the external communication to the customer. Finally, GAP 5 is a failure that is due to the other four, it presents the difference between the expected quality and the service perceived by the customer.

\section{METHOD}

This study is descriptive and with a quantitative approach. As methodological research strategies, field study and descriptive statistics were used. The field study used interview and observation techniques to collect information about the microenterprise and the use of a questionnaire with consumers to capture data on service quality. Descriptive statistics used mean and standard deviation.

Data were collected through a questionnaire based on the service quality measurement scale known as SERVQUAL. It is a structured questionnaire with closed questions that has a Likert scale adapted to 7 graduation levels, ranging from 1 that shows total disagreement with the statement to 7 that means total agreement with the statement. The variables used to generate the descriptors are identified in the literature in five dimensions: tangible, reliability, responsiveness, security and empathy (MENEZES et al., 2016; CARVALHO et al., 2019).

The sample is configured as non-probabilistic for convenience made with company users, here named with the fictitious name of VegXYZ, located in the city of Campinas-SP. There was a pre-test with 9 individuals and the final collection with 35 individuals, both stages carried out in the second half of 2020. It should be stressed that capacity restrictions, sanitary protocols for social distancing, access control and use were followed to carry out this event mandatory use of masks and provision of alcohol gel.

As a methodological strategy of the field research, the 35 individuals were placed in the same physical environment in order to bring all elements of the group closer to the most similar "moment of truth", in order to reduce objective elements such as the variability of 
services, perishability of items and differentiated logistic treatment due to volume. With this, the group had the same impression of the equipment, service and offer.

It was explained to the group how the research dynamics would be carried out, which was divided into three parts: collection of expectations; order request; collection of perceptions. The expectation questionnaire consisted of 22 closed questions arranged in Table 1 , which aimed to measure the desired level for a restaurant in the savory market. The questionnaire was completed without the intervention of the researcher.

Table 1 - SERVQUAL Scale Questionnaire

\begin{tabular}{|c|c|c|c|c|c|c|}
\hline Items & \begin{tabular}{|l|l|l|l}
1 & 2 \\
\end{tabular} & \begin{tabular}{l|l}
2 & 3
\end{tabular} & 4 & 5 & & 7 \\
\hline 1.Snack food companies have modern equipment. & & & & & & \\
\hline 2. The physical environment of the snack companies is pleasant. & & & & & & \\
\hline 3. Employees of snack companies look good. & & & & & & \\
\hline $\begin{array}{l}\text { 4. The material associated with the service provided by the snack } \\
\text { companies has a good visual appearance. }\end{array}$ & & & & & & \\
\hline $\begin{array}{l}\text { 5. When snack companies promise to do something in a certain } \\
\text { amount of time, they deliver. }\end{array}$ & & & & & & \\
\hline $\begin{array}{l}\text { 6. When customers have a problem, snack companies are friendly and } \\
\text { reassuring. }\end{array}$ & & & & & & \\
\hline 7. The snack companies get the job right the first time. & & & & & & \\
\hline $\begin{array}{l}\text { 8. The snack companies perform their services at the time they are } \\
\text { committed. }\end{array}$ & & & & & & \\
\hline 9. Snack food companies keep correct information and records. & & & & & & \\
\hline $\begin{array}{l}\text { 10. Employees of snack companies promise customers the services by } \\
\text { the time they will be performed. }\end{array}$ & & & & & & \\
\hline $\begin{array}{l}\text { 11. Employees at the snack food companies offer prompt customer } \\
\text { service. }\end{array}$ & & & & & & \\
\hline $\begin{array}{l}\text { 12. Employees in snack companies must always be willing to help } \\
\text { customers. }\end{array}$ & & & & & & \\
\hline $\begin{array}{l}\text { 13. Employees at snack food companies are never too busy to answer } \\
\text { customer questions. }\end{array}$ & & & & & & \\
\hline $\begin{array}{l}\text { 14. The behavior of employees of snack companies inspires trust in } \\
\text { customers. }\end{array}$ & & & & & & \\
\hline 15. Customers feel secure in their transactions with snack companies & & & & & & \\
\hline $\begin{array}{l}\text { 16. Employees of snack companies are polite and courteous to their } \\
\text { customers. }\end{array}$ & & & & & & \\
\hline $\begin{array}{l}\text { 17. Employees in snack companies have the knowledge to answer } \\
\text { customer questions. }\end{array}$ & & & & & & \\
\hline 18. Snack food companies give individual attention to each customer. & & & & & & \\
\hline $\begin{array}{l}\text { 19. Snack food companies have convenient opening hours for all their } \\
\text { customers. }\end{array}$ & & & & & & \\
\hline
\end{tabular}




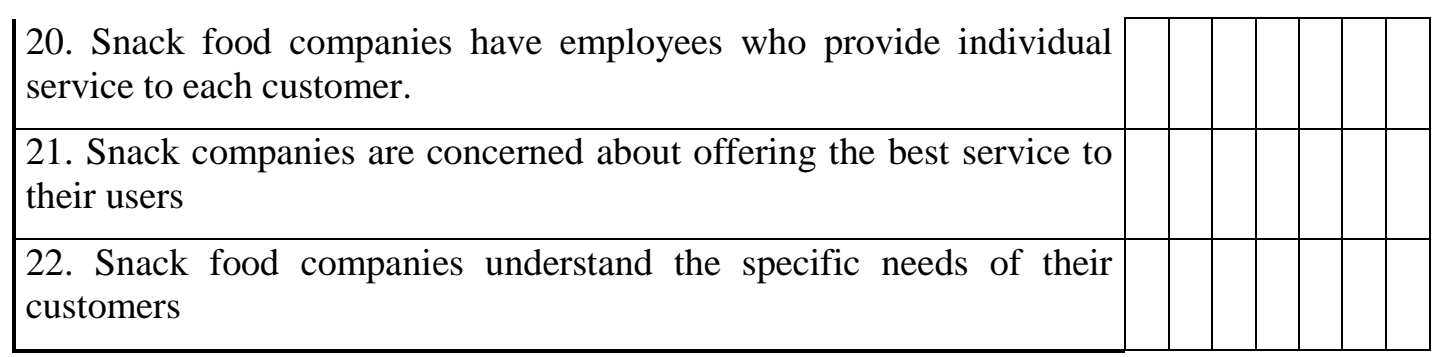

Source: Adapted from Parasuraman, Zeithaml e Berry (1988) and Menezes et al., (2016)

In a second moment, the group was told how they should proceed to execute the request. This step was mediated by a digital food delivery application that generated a specific virtual room for those users to interact and consolidate orders in different orders for the same place and time. With this, the contact with the company's items such as menu, offer, service, equipment were made through the food delivery application. After a while, a problem was forced through the application and a need to change the order to comply with situations measured in the questionnaire.

In a third moment, after receiving the request, the second questionnaire was applied, consisting of 22 closed questions similar to the first questionnaire, however adapting the questions for the company evaluated, shown in Table 2.

Table 2 - SERVQUAL Scale Questionnaire for VegXYZ

\begin{tabular}{|c|c|c|c|c|c|c|}
\hline Items & \begin{tabular}{|l|l|l|l}
1 & 2
\end{tabular} & \begin{tabular}{|l|l|}
2 & 3
\end{tabular} & 4 & 5 & & 7 \\
\hline 1. VegXYZ Company has modern equipment. & & & & & & \\
\hline 2. The physical environment of VegXYZ Company is pleasant. & & & & & & \\
\hline 3. Employees of VegXYZ Company look good. & & & & & & \\
\hline $\begin{array}{l}\text { 4. The material associated with the service provided at VegXYZ Company has a } \\
\text { good visual appearance. }\end{array}$ & & & & & & \\
\hline $\begin{array}{l}\text { 5. When VegXYZ Company promises to do something at a certain time, it } \\
\text { delivers. }\end{array}$ & & & & & & \\
\hline $\begin{array}{l}\text { 6. When customers have a problem, VegXYZ Company is friendly and } \\
\text { reassuring. }\end{array}$ & & & & & & \\
\hline 7. VegXYZ Company does the job right the first time. & & & & & & \\
\hline 8. The VegXYZ Company performs its services at the time it is committed. & & & & & & \\
\hline 9. The VegXYZ Company maintains correct information and records. & & & & & & \\
\hline $\begin{array}{l}\text { 10. Employees of VegXYZ Company promise customers the services within the } \\
\text { timeframe in which they will be performed. }\end{array}$ & & & & & & \\
\hline 11. VegXYZ Company employees provide prompt customer service. & & & & & & \\
\hline 12. VegXYZ Company employees are always willing to help customers. & & & & & & \\
\hline $\begin{array}{l}\text { 13. Employees of the VegXYZ Company are never too busy to answer } \\
\text { customer queries. }\end{array}$ & & & & & & \\
\hline $\begin{array}{l}\text { 14. The behavior of employees of the VegXYZ Company inspires trust in } \\
\text { customers. }\end{array}$ & & & & & & \\
\hline
\end{tabular}




\begin{tabular}{|l|l|l|l|l|l|}
\hline 15. Customers feel secure in their transactions with VegXYZ Company. & & & & & \\
\hline 16. VegXYZ Company employees are polite and courteous to their customers. & & & & \\
\hline $\begin{array}{l}\text { 17. VegXYZ Company employees have the necessary knowledge to answer } \\
\text { customer questions. }\end{array}$ & & & & & \\
\hline 18. VegXYZ Company provides individual attention to each customer. & & & & \\
\hline $\begin{array}{l}\text { 19. VegXYZ Company has convenient hours of operation for all of its } \\
\text { customers. }\end{array}$ & & & & & \\
\hline $\begin{array}{l}\text { 20. The VegXYZ Company has employees who provide individual assistance to } \\
\text { each customer. }\end{array}$ & & & & & \\
\hline $\begin{array}{l}\text { 21. The VegXYZ Company is concerned with offering the best service to its } \\
\text { users. }\end{array}$ & & & & & \\
\hline 22. The VegXYZ Company understands the specific needs of its customers. & & & & \\
\hline
\end{tabular}

Source: Elaborated by the authors

At the end of the data collection stage, the tabulation took place through the use of Microsoft Excel 2010. For the treatment of the collected data, Microsoft Excel 2010 was also used. In this last stage, the analysis of the SERVQUAL model, subtracted the values from expectations by the value of the perception to obtain the value of the GAPs between the desired and the perceived service. At this stage it will be understood that the more negative the value, the greater the understanding of the inferiority of the quality of the service by users, and the positive and greater the value, the greater the understanding that there was an excellent service provision. Afterwards, a descriptive statistical analysis of the mean and standard deviation of each of the descriptors and dimensions analyzed is carried out.

\section{RESULTS AND DISCUSSION}

The company VegXYZ is a family business, established in the city of Campinas-SP and has been formally operating for two years in the fried and baked snacks business. The team consists of a cook, an attendant and a delivery person. In the product portfolio offered by the company, there are currently 18 items. All items are vegan, so this is a company that offers vegan food options.

The order processing process starts with the customer entering the order information and formally ordering through the application in which the company is embedded. The transmission of information to those who will handle the order is done electronically and to face-to-face customers it is done manually.

For service, the attendant receives the order, checks the information and, if any, the observations of different orders, analyzes the possibility of service due to availability and accepts to place the order. There follows an order of cooking for the kitchen and at the same time internal and external documents are prepared. The kitchen produces the order using instock resources or/and previously stored prepared products to speed up service. The company follows the policy of the first order received, it is the first to be processed. After production is complete, the order is packaged and sent for service. 
The service schedules the delivery taking into account other deliveries to consolidate the order and the estimated delivery time, checks what was produced and dispatches the delivery person with the order and the customer's document. After this, the attendant informs the customer through the dispatch application. The simultaneous tracking service of the exact location of the delivery person is not yet offered. The procedure ends with the completion of the operation in the application.

Chart 1 below shows the result of applying the SERVQUAL scale to measure the quality of services provided by VegXYZ.

Chart 1 - Results of applying the SERVQUAL Scale in the VegXYZ company

\begin{tabular}{|c|c|c|c|}
\hline \multirow[b]{3}{*}{ Dimensions and dimension descriptors } & \multicolumn{3}{|c|}{$\begin{array}{l}\text { Expectation } \\
\end{array}$} \\
\hline & Perception (P) & & GAP \\
\hline & \multicolumn{3}{|c|}{$\begin{array}{l}\text { Mean Standard- Mean Standard- } \\
(\mathrm{X}) \quad \text { Deviation }(\mathrm{X}) \quad \text { Deviation }\end{array}$} \\
\hline \multicolumn{4}{|l|}{ A - Tangibility } \\
\hline 1- Modern equipment & $5,2860,8980$ & $4,8570,8163$ & 0,429 \\
\hline 2- Pleasant physical environment & $5,2001,0286$ & $5,0860,7412$ & 0,114 \\
\hline 3 - Good looking employees & $5,2570,9796$ & $5,0000,8571$ & $\mathbf{0 , 2 5 7}$ \\
\hline 4 - Good looking advertising material & $5,5141,0122$ & $5,0290,7249$ & 0,486 \\
\hline \multicolumn{4}{|l|}{ B - Reliability } \\
\hline 5 - Compliance with the deadline & $5,6860,7984$ & $5,4000,9600$ & 0,286 \\
\hline 6 - Interest in solving problems & $5,5430,9012$ & $5,1711,1004$ & 0,371 \\
\hline 7 - Getting the job done right the first time & $5,8000,8800$ & $5,3710,9894$ & 0,429 \\
\hline 8 - Service as offered & $5,8860,9567$ & $5,3430,8865$ & 0,543 \\
\hline 9 - Tasks performed without errors & $5,7140,8000$ & $5,0571,1478$ & 0,657 \\
\hline \multicolumn{4}{|l|}{ C - Responsiveness } \\
\hline Customers kept informed & $5,7710,8327$ & $5,2000,6286$ & 0,571 \\
\hline Emergency Service & $5,7710,7837$ & $5,2570,8229$ & 0,514 \\
\hline Interest in helping & $5,6000,8457$ & $5,3430,8310$ & 0,257 \\
\hline Availability to assist & $5,1710,7967$ & $5,3140,9306$ & $-0,143$ \\
\hline \multicolumn{4}{|l|}{ D - Security } \\
\hline Employees transmit confidence & $5,7710,7837$ & $5,2000,8343$ & $\mathbf{0 , 5 7 1}$ \\
\hline Security transmitted during transaction & $5,6570,8294$ & $5,2860,7755$ & $\mathbf{0 , 3 7 1}$ \\
\hline courteous representatives & $5,8860,6269$ & $5,2860,7755$ & 0,600 \\
\hline Knowledge and competence needed for questions & $5,7430,8229$ & $5,2570,7951$ & 0,486 \\
\hline \multicolumn{4}{|l|}{ E - Empathy } \\
\hline individual attention & $5,2860,8980$ & $4,9430,9322$ & 0,343 \\
\hline Convenient office hours & $5,6001,2000$ & $5,1430,9796$ & 0,457 \\
\hline
\end{tabular}




$\begin{array}{llll}\text { Personalized service } & 5,1711,0531 & 4,8290,9959 & \mathbf{0 , 3 4 3} \\ \text { Interest in offering better service } & 5,7430,9371 & 4,9430,9894 & \mathbf{0 , 8 0 0} \\ \text { Understanding the specific needs } & 5,5430,9845 & 5,0861,1265 & \mathbf{0 , 4 5 7}\end{array}$

Source: Made by the authors

In relation to expectations, in general, respondents have high expectations in the provision of service from a reference company in this type of segment, in most factors, the average was above five. It is also possible to infer that expectations about the Empathy dimension were the lowest compared to the other dimensions. Responsiveness was the dimension in which respondents had the greatest expectation that a model company should offer quality of service.

Regarding the perceptions obtained, a good level of receipt of services is verified, because the averages of the dimensions are above five, which represents agreement with the aspects judged. The Security dimension was the best evaluated, while the Tangibility dimension had, compared to the others, the lowest evaluative score.

Regarding GAPs, the central point of the SERVQUAL analysis, a slightly positive result was found in 21 of the 22 aspects evaluated, 95\% of the criteria. The descriptor dealt with the availability of an assistant obtained a slightly negative result, approximately -0.143 . In general, the Responsiveness dimension had the smallest variation in the GAP, indicating greater proximity between expectation and perceived quality, while the Safety dimension had the greatest variation between expectation and perceived quality.

Regarding the company's weakest point, this was the Responsiveness dimension. Particularly, it was also in this factor that a negative discrepancy was found. This factor is intrinsically linked to the human part, although mediated by the application. Thus, this is a point that deserves attention and possible action by the company.

When interpreting the results offered by the analysis dimensions and the gaps between perception and expectation, it is possible to infer that the service offered contributes positively to the consumer's perception of the quality of the service. This result applies to all dimensions, making it possible to state that the company accurately performs the service as promised, has physical, human and technological resources that denote the knowledge needed to perform their routine and skills to inspire credibility and individually assist consumers during your service.

In general, studies that perform the SERVQUAL analysis have a greater amount of negative discrepancy, something that was minimally found in this study. The company's strengths are the reliability of the offer and security. Several factors of these dimensions, as well as others, are influenced or directly carried out through the fast food and drink delivery application.

The delivery app contributes to the highest level of quality by offering the user prior registration, preferences, filtering options, order calculation, waiting time, location of the place in relation to its location, restaurant situation, menu, photos, and diversified payment method. However, the fact that there is a difficult direct communication channel with the company to resolve doubts and undertake requests makes a negative aspect appear for the customer. 


\section{FINAL CONSIDERATIONS}

The service sector has grown over the years, contributing to economic development: by generating jobs and opening new ventures. At the organizational level, the current pandemic has had impacts such as: layoffs, non-payment, reduced sales, closure of units and shortage of supplies. At a time when social distancing measures and public health safety standards prevail, many companies have undergone profound organizational changes.

Aware that, faced with this scenario, micro and small companies, when facing difficulties, choose to reduce costs that reflect on the quality of the service provided, this study aimed to identify and assess the quality offered by a vegan microenterprise in the field of fried and baked snacks that provides its services through the use of a delivery app.

Due to the results obtained, it is possible to conclude that the service offered by this enterprise contributes positively to the consumer's perception of the quality of the service in all dimensions evaluated. In most of these operational actions there is mediation by the order processing application, a fact that highlights the importance of using this tool in economic enterprises. In this way, by obtaining superior performance, the company has a competitive advantage over its competitors.

The theoretical-practical knowledge acquired and provided by this work can support micro-entrepreneurs who are faced with situations similar to the case studied, with regard to the business model, sector and contextual difficulties. For future studies, it is first suggested to compare the finding of this study with other enterprises in the same sector, and the second suggestion is to compare the quality perceived by consumers through different channels of interaction with the service provider.

\section{REFERENCES}

\section{ASSOCIAÇÃO NACIONAL DE RESTAURANTES; GALUNION. Alimentação na}

Pandemia: a visão dos operadores de foodservice. 2020. 46 p. Retrieved from: https://conteudo.galunion.com.br/pesquisa-com-operadores-do-foodservice-galunion-anr.

Access in: 10 nov. 2020.

BAPTISTELLA, E. S. T.; ABONIZIO, J. O peso dos animais nas urnas: uma reflexão sobre o papel dos animais na política contemporânea. Revista Brasileira de Ciência Política, v. 22, p. 329-372, 2017.

BARROS, K. S. Padrões de dieta de universitários no Sul do Brasil. 2019. 148 f. Dissertação (Mestrado em Epidemiologia). Universidade Federal de Pelotas, Pelotas, RS.

CERETTA, S. B. N.; FROEMMING, L. M. S. Geração Z: Compreendendo os Hábitos de Consumo da Geração Z. Revista Eletrônica Mestrado em Administração, v.3, p. 15-24, 2011.

CARVAlHO, L. M.; LAMEIRAS, M. A. P.; MORAES, M. L. Carta de Conjuntura, IPEA, número 47, $2^{\circ}$ trimestre de 2020. Boletim de acompanhamento setorial da atividade econômica. Disponível em: https://www.ipea.gov.br/cartadeconjuntura/wpcontent/uploads/2020/05/200526_beltim_final_III.pdf. Acesso em: 30 jun. 2020. 
CARVALHO, M. L. F.; NEVES, S. M.; CAMPOS, L. B. P.; OLIVEIRA, C. H. Aplicação da ferramenta SERVQUAL para análise da qualidade em serviços e benchmarking: estudo de caso em empresas varejistas. GEPROS. Gestão da Produção, Operações e Sistemas, v. 15, p. 22-47, 2019.

FREIRIA, C. A.; SOUZA, J. S.; COUTO, L. R. R.; CRUZ, M.; SARRETA, M. Campanha de Comunicação Ahimsa-Vegan Life. 2017. 98 f. Monografia (Graduação em Comunicação Social) - Centro Universitário Municipal de Franca, Franca.

GRÖNROOS, C. Marketing: gerenciamento e serviços: a competição por serviços na hora da verdade. Rio de Janeiro: Campus, 1995.

INSTITUTO BRASILEIRO DE GEOGRAFIA E ESTATÍSTICA. Pesquisa de orçamentos familiares 2008-2009: despesas, rendimento e condições de vida. Rio de Janeiro: Instituto Brasileiro de Geografia e Estatística; 2011.

INSTITUTO BRASILEIRO DE GEOGRAFIA E ESTATÍSTICA. Pesquisa de orçamentos familiares 2017-2018: primeiros resultados. IBGE, Coordenação de Trabalho e Rendimento. Rio de Janeiro: Instituto Brasileiro de Geografia e Estatística, 2019.

INSTITUTO BRASILEIRO DE GEOGRAFIA E ESTATÍSTICA. Pesquisa de orçamentos familiares 2017-2018: análise do consumo alimentar pessoal no Brasil / IBGE, Coordenação de Trabalho e Rendimento. - Rio de Janeiro: IBGE, 2020.

IBOPE. Pesquisa de opinião pública sobre vegetarianismo. 2012. Disponível em: <https://www. ibope.com.br>. Acesso em: 20 abr. 2020.

KOTLER, P.; ARMSTRONG, G. Princípios de marketing. São Paulo: Pearson, 2015.

MENEZES, N. K. B.; ABRANTES, L. A. M.; NEPOMUCENO, D. L. M.; JAYME NETO, O. Aplicação do Modelo SERVQUAL para medir a qualidade dos serviços prestados por uma empresa de locação de máquinas. In: XII CONGRESSO NACIONAL DE EXCELÊNCIA EM GESTÃO, 2016, Rio de Janeiro: XII Congresso Nacional de Excelência em Gestão, 2016.

NETO, J. PIB cresce 1,1\% pelo segundo ano seguido e fecha 2018 em R \$ 6,8 trilhões. Agência IBGE Notícias, 28 fev. 2019. Retrieved from: https://agenciadenoticias.ibge.gov.br/agencia-noticias/2012-agencia-denoticias/noticias/23885-pib-cresce-1-1-pelo-segundo-ano-seguido-e-fecha-2018-em-r-6-8trilhoes. Access in: 18 mai 2020.

PARASURAMAN, A.; BERRY, L. L; ZEITHAMLL, V. A. Conceptual Model of Service Quality and Its Implications for Future Research. The Journal of Marketing, Vol. 49, n. 4, 12-40, 1985.

PARASURAMAN, A.; BERRY, L. L; ZEITHAMLL, V. A. SERVQUAL: a multiple-item scale for measuring consumer perceptions of service quality. Journal of Retailing, New York, v. 64, n. 1, p.12-40, Spring 1988.

QUINN, J; GAGNON, C. Will services follow manufacturing into decline? Harvard Business Review, p. 92-103, 1986.

QUINN, J; GAGNON, C. Will services follow manufacturing into decline? Harvard Business Review, p. 92-103, 1986.

RÉVILLION, Jean Philippe; KAPP, Carolina; BADEJO, Marcelo Silveira; DIAS, Valéria da Veiga. O mercado de alimento de alimentos vegetarianos e veganos: características e perspectivas. Cadernos de Ciência \& Tecnologia, 37 (1), 1-10, 2020.

Refas - ISSN 2359-182X v.8, n.1

Outubro de 2021 
RIBEIRO, U. L. A ascensão do consumo ético de produtos vegetarianos e veganos no mercado brasileiro, Revista Observatorio de la Economía Latinoamericana, 3(12), 1-12, 2019.

ROSA, R. A. Gestão de Operações e Logística. 1. ed. Florianopólis: Sistema Universidade Aberta do Brasil - CAPES/MEC, 2011.

SCHIFFMAN, L.; KANUK, L. L. Comportamento do consumidor. 6. ed. Rio de Janeiro: LTC, 2000.

TOMOYOSE, F. H. A Influência do Nível de Serviço Logístico na Satisfação do Cliente: um Estudo em Montadora do Setor Automobilístico. 2014. 184 f. Dissertação (Mestrado em Administração) - Universidade Municipal de São Caetano do Sul, São Caetano do Sul. 